T

\title{
Pedagogical leadership and educational management in the teaching practice of SENA - Colombia
}

\author{
Verónica Johana Suárez Molina1, José Luis Rodríguez López2, Judith Soledad Yangali Vicente3 \\ ${ }^{1}$ Corporación Universitaria Minuto de Dios \\ ${ }^{2}$ Universidad Tecnológica del Perú \\ ${ }^{3}$ Universidad Norbert Wiener \\ 1verosu6@gmail.com 21uisjoserodriguez1512@gmail.com, 3judith.yangali@uwiener.edu.pe
}

\begin{abstract}
The purpose of the research was to determine the influence of pedagogical leadership and educational management on the teaching practice of the SENA's technical and technological training centers in Colombia. The study has a mixed approach, in the quantitative approach it was the non-experimental design and in the qualitative approach it followed the phenomenological-hermeneutic design. For the quantitative study, the population was made up of 201 professional instructors, located in 33 regions of Colombia where the SENA is present, and for the qualitative study, 8 teaching directors. The application instruments were a questionnaire and a semi-structured interview guide. In conclusion, there is a relationship between the influence of the pedagogical leadership of the direction and the educational management in the teaching practice of the SENA training centers in Colombia
\end{abstract}

Index Terms

Pedagogical leadership, educational management, teaching practice, training centers

Article Received: 10 August 2020, Revised: 25 October 2020, Accepted: 18 November 2020

\section{Introduction}

The theories associated with leadership styles have responded to the social, economic and cultural conditions of each era. Thus, throughout history, the field of study has been consolidated according to the vision of different civilizations with different positions on power [26]. The beginning of the industrial revolution formally initiated the generation of management and leadership programs. Its development marked a milestone in the production processes in organizations, given the technification and planning that allowed conceiving time as a significant variable in the quality and execution of activities with efficiency and effectiveness [30]. However, in the 80's, the leader has been defined by the capabilities and actions related to management, teamwork, ability in the distribution of functions and influence [33]. In this way, a gestation of leadership is generated at the organizational level and the definitions and theoretical applications associated with the disciplines are projected, among them; the theory of relationships, in which the leader manifests the ability to generate ownership, commitment and loyalty on the part of his followers [2], [30].

From this epistemological perspective, the conception of leadership styles is defined according to the macro context in which the leader assumes his leadership position in an organization. Thus, the related theoretical contributions converge in educational institutions, based on the vision of organization that emerged in the decade of [3], [15].

In this way, theoretical positions are consolidated that indicate the characteristics that an educational leader should have, and that can be defined according to their behavior, the ordinary leader who establishes purposes and fulfills results, the innovative leader who encourages and proposes strategies, and the visionary leader who projects and promotes the evolution of his team and the organization [14]. However, the definition of a pedagogical leader originates from his or her role as a designer of processes in which he or she is encouraged to think and rethink his or her management, the vocation of being a leader, and the practice of teaching his or her community [28]. Likewise, it is important that pedagogical leaders show a stable leadership style for the development of efficient practices, even when, due to the accelerated dynamics in which society finds itself, situations of complexity and constant changes arise that generate the adaptation and adaptability of processes [20]. Thus, pedagogical leadership in today's higher education institutions is consolidated as an ability to successfully guide the academic and administrative results of an educational community, with the objective of increasing its response capacity in adverse situations and increasing its competitive advantage [20]. For this reason, the importance of applying pedagogical leadership strategies that are articulated with educational models that enable the development of organizations [6].

In Latin America, Peru, Brazil, Mexico, Chile and Argentina, the definition and function of the teaching manager is regulated according to State guidelines. Their definitions coincide in that there is a multiplicity of functions that are alluded to the position [22], a situation that is not different in Spain, where the teaching managers of training centers assume a multiplicity of administrative, academic and legal functions, which seek to guarantee through adequate management the development and organizational progress of the institution and its community [25].

In Colombia, the country in which this research was conducted, educational institutions were seen as isolated organizations. The National Learning Service SENA, a higher education institution for technical and technological training, retains a top-down pedagogical leadership style 
T

[23], 23], in which hierarchical structures and a solid network of public managers who devote their mission to the fulfillment of training functions and goals set by the national government prevail, recognizing from their role functions associated with strategic direction, school governance, organizational culture and climate, and community relations [22], [34], [25].

For this reason, the importance of knowing and determining the influence of the pedagogical leadership of the educational direction and management in the teaching practice, in order to understand the characteristics of the pedagogical leader, his role in the training centers and his influence in the pedagogical accompaniment and the linking of the teaching staff in managerial activities.

This article begins by presenting the theories from which the conception of pedagogical leadership, educational management and teaching practice is argued, followed by the definition of the method implemented for the testing of hypotheses, and the results in which the main findings of the application of the quantitative and qualitative approach of the research are consolidated. Subsequently, the final considerations of the descriptive and inferential analysis in the application of instruments are presented. Finally, in the discussion section, the arguments that support the definition of pedagogical leadership, from the theory of relationships, distributed leadership and pedagogical accompaniment, are presented.

\section{Development Of Contents}

\section{A. Pedagogical leadership}

Research conducted in recent years has made significant contributions to the conception of pedagogical leadership by proposing new management practices in educational contexts that make it possible to define the leader's leadership style according to the needs of the context and culture [27]. From this perspective, a conception of leadership in training centers associated with the ability to enhance skills that encourage the recognition of the aptitudes of others, allow teamwork, develop collective strengths and influence others to achieve institutional purposes is assumed [5].

Thus, the contributions of pedagogical leadership in educational practices have made it possible to solve the academic problems that arise in the institutions, from an approach based on relationships that promotes distributed leadership, which is developed under principles of autonomy and trust, achieving better community results from the assignment of roles and mutual collaboration [31]. However, it is important that a leadership proposal is structured by the educational leader, which is characterized by the conditions of each institution, its context and the leader's personality [27].

There are various theoretical positions that indicate the actions that an educational leader should take. However, most of them converge in improving educational management, providing ongoing pedagogical support and achieving the purposes and goals set by the work teams [21]. In this sense, it is important that educational leaders show a stable leadership style for the development of efficient practices, even when, due to the accelerated dynamics in which society finds itself, situations of complexity and constant changes arise that generate adaptation and adaptability in the processes [8].

In this way, a direct influence of the educational leader in the management processes is established, which requires actions associated with the development of friendly relationships with his collaborators, with respect and authority, the generation of a space of trust by the educational community, for his management and commitment, understanding the particular needs not only from the knowledge of the person, but also from the surrounding context, minimizing work stress, considering the requests of all collaborators and ensuring the promotion of an organizational climate based on relationships of respect, harmony, teamwork and trust in the work performed [29].

\section{B. Educational management}

Educational management is a recent theoretical field, which began with the development of scientific contributions in Anglo-Saxon and European countries from the conception of educational institutions as organizations [13]. Thus, conceptually, the term educational management takes up the concept of management, approached from the business context, in order to recognize its application in the educational context [22]. However, efforts have been made by different theorists and educators to clarify its relationship not only with administrative processes, but also with academic processes, aspects that are not taken into account in the original approach to the definition and practice [12].

Due to the strong semantic designation that has been attributed to the term management, it is pertinent to highlight two approaches in the educational context: the first, associated with bureaucratic management, which is essentially determined by the administration of material and human resources available to institutions; and the second, related to quality management, which is determined by the generalized vision of organizations [17].

Similarly, the theoretical confusion and debate of some authors between the definition of the concepts of educational management and administration is recognized, because the first term determines a pedagogical, academic and humanistic approach, while the second focuses on the business context. However, this position of Latin American origin has been addressed in American educational research, in which it has been possible to take a position and affirm that educational administration and educational management are synonymous and therefore can be implemented indistinctly [18]. Consequently, in the 1990's, the application of the management process became more relevant, which made it possible not only to conceive the term from theory but also from practice, different academic, political and directive statements that made it possible to define the centralization or decentralization of educational organizations according to social structures and educational management [12].

From a recent Latin American perspective, educational management is defined as a systematic process that enables organizational change by developing strategies that allow for innovation in the application of management strategies that are adapted to the educational communities. In this way, 
educational leaders are able to consolidate a management process that is flexible, strategic and perceptive of the needs of educational institutions according to the context in which they operate and develop their citizenship training processes [36]. Some dimensions proposed for the analysis of educational management are the pedagogical dimension, which focuses on comprehensive training, curriculum programming, curriculum design and development, among other aspects of the academic component, the administrative dimension, related to the management of resources for training, human talent management, management of physical resources, materials and infrastructure, and the community dimension, focused on the recognition of the needs of the educational community [36].

However, from another perspective, there is a need to link the analysis of the dimensions of educational management with actions related to strategic direction. Hence, aspects such as strategic management, which is aimed at achieving organizational goals and achievements from the action of a collective, administrative management, dedicated to the management of human talent, physical and economic resources and supervision of the application of the standard in order to achieve educational quality in the processes and academic management, related to the definition of academic guidelines that allow centralizing training processes with the aim of achieving institutional goals are linked [13].

\section{Teaching practice}

In academic management, different actors intervene to enrich the teaching-learning process and dynamize the pedagogical practice with the aim of improving the development of student learning [10] from bidirectional relationships in which the construction of knowledge between teacher and student takes place. For this reason, nowadays, teaching practice is studied theoretically, and the relationship of educational management in the processes of pedagogical accompaniment and linking teachers in management activities.

In this way, it is identified the strong relationship that is built between teachers and students in a learning environment, which is characterized by the social and cultural conditions of the educational context [11], allowing the exercise of a teaching practice that is associated with the development of personal, interpersonal, social, didactic and valuation dimensions, in which it is possible to know, the execution of the practice, academic relationships, the achievement in the design of resources that strengthen the pedagogical accompaniment and the assessment and continuous improvement of the educative work [37].

This is how teaching practice is defined from the teacher's work that contributes to the development of basic and generic competencies that promote knowledge from an integral formative process, which is generated from participation, communication, interaction and the application of didactics and methodologies according to the educational context of the students [9]. For this reason, the need to structure the educational model still implemented in educational institutions, moving from a traditional teaching approach to one based on construction and participation, which encourages the development of skills so that the student acquires the competitiveness and skills necessary to be autonomous in society [9].

In accordance with the above, currently a pedagogical leadership is identified that is characterized by its management in the development of learning and the efficient accompaniment of teachers to ensure good teaching practices [4]. In this sense, five fundamental principles that an educational leader should follow in the framework of his or her management are identified, such as creating the necessary conditions for a good organizational climate, promoting relationships for learning, encouraging dialogues about leadership and learning, applying distributed leadership, collectively assuming responsibility for the results, and designing improvement strategies [19]. Thus, the creation of an educational organizational culture focused on teaching practices and their main results is defined, from a unified vision in the execution of tasks with quality and efficiency according to institutional goals and purposes [5]. Consequently, it is recognized the richness of an educational leader characterized by a pedagogical leadership style that complies with the support, accompaniment and evaluation of the teaching practice of their teachers [24], and in turn, by the development of an academic management focused on the quality of teaching and, as a consequence, on the efficient learning of students [5].

From this perspective, it is insisted on the application of a distributed leadership where all members of the institution can act, achieving the linkage of the faculty in activities not only academic but also administrative (Garcia-Garnica, 2016), applying five practices that show the effectiveness of pedagogical leadership and educational management in teaching practices and that have a great impact on learning such as; establishing a direction, keeping in mind the institutional vision, being interested in staff development; redesigning the institution from the promotion of a collaborative culture, and managing teaching and learning programs [35].

\section{Methodology}

\section{A. Method}

The methodology was structured from the definition of two study methods. The first, hypothetical-deductive or hypothesis testing [16], approached from the application of the quantitative approach in the first phase of the study. The second, inductive, consisted of two inverse procedures, induction and deduction [16], which seek to understand in the second phase of the study, from the qualitative approach, the similarities of the individual phenomena in order to reach conclusions or aspects that provide an answer to the general problem.

\section{B. Research objective and hypothesis}

To determine the influence of the pedagogical leadership of the educational direction and management on the teaching practice of the SENA. 


\section{General hypothesis}

Ho. The pedagogical leadership of the management and educational management influence the teaching practice of SENA - 2020.

\section{Specific hypotheses}

H1. The pedagogical leadership of the direction and the educational management influence the accompaniment to the formative processes of SENA - 2020.

H2. The pedagogical leadership of the direction and educational management influence the linkage of teachers in managerial activities of SENA - 2020.

\section{Research design}

From the quantitative approach, a causal correlational nonexperimental design was determined, in which the variables are not deliberately manipulated; on the contrary, it alludes to the observation of already existing situations that support the formulation of the problem [16], from the data collection obtained from the adaptation of the questionnaire effective practices of pedagogical leadership in educational institutions [13]. Likewise, from the application of the qualitative approach, a phenomenological-hermeneutic design was approached [16], which had the purpose of understanding the experiences of people in relation to the study phenomenon, from the application of the adaptation of a semi-structured interview guide [25].

\section{Population and sample}

In the development of the study, the population was assumed to be 8 teaching managers and 3330 instructors located in 118 training centers of the National Learning Service SENA of Colombia, a higher education entity of the official education sector, established in the Andean, Caribbean, Pacific, Amazonian and Orinoco areas where it converges with the presence of 33 regions where one or more SENA training centers are located. According to the above, the sample defined for the quantitative study with a level of $95 \%$ was 201 instructors.

\section{Results}

\section{A. Descriptive analysis}

The development of the descriptive analysis of the variables pedagogical leadership, educational management and teaching practice, each with their respective dimensions, was carried out by defining rating scales. In accordance with this, the distribution analysis of each variable was carried out, recognising initially for the pedagogical leadership variable that of the total of 201 instructors in the regions of Colombia, $20.9 \%$ perceive a deficient level of collaboration beyond the school dimension on the part of the teaching managers of the training centres, $59.7 \%$ a fair level and $19.4 \%$ a good level.

In the second dimension related to their ability to share leadership, $0.5 \%$ of trainers perceive a poor level, $20.40 \%$ a fair level and $41.7 \%$ a very good level. In the third dimension related to training in pedagogical skills, $17.4 \%$ of the management considered the level to be fair, $40.8 \%$ a good level and $41.7 \%$ a very good level. And for the fourth dimension, associated with making leadership an attractive profession, $13.9 \%$ of the instructors perceived by the management a fair level, 33.3\% a good level, and $52.7 \%$ a very good level Table I.

Tabla I. Niveles de distribución de las dimensiones del

\begin{tabular}{|c|c|c|c|c|c|c|c|c|c|c|}
\hline \multicolumn{11}{|c|}{ liderazgo pedagógico } \\
\hline & \multicolumn{2}{|c|}{ Poor } & \multicolumn{2}{|c|}{ Fair } & \multicolumn{2}{|c|}{ Good } & \multicolumn{2}{|c|}{ Very good } & \multicolumn{2}{|l|}{ Total } \\
\hline & $\mathrm{n}$ & $\%$ & $\mathrm{n}$ & $\%$ & $\mathrm{n}$ & $\%$ & $\mathrm{n}$ & $\%$ & $\mathrm{n}$ & $\%$ \\
\hline $\begin{array}{l}\text { Collaboration } \\
\text { beyond the school }\end{array}$ & 42 & 20.9 & 120 & 59.7 & 39 & 19.4 & 0 & 0.0 & 201 & 100 \\
\hline $\begin{array}{l}\text { Ability to share } \\
\text { leadership }\end{array}$ & 1 & 0.5 & 41 & 20.4 & 75 & 37.3 & 84 & 41.7 & 201 & 100 \\
\hline $\begin{array}{l}\text { Training in } \\
\text { pedagogical skills }\end{array}$ & 0 & 0.0 & 35 & 17.4 & 82 & 40.8 & 84 & 41.7 & 201 & 100 \\
\hline $\begin{array}{l}\text { Making } \\
\text { leadership } \\
\text { attractive } \\
\text { profession }\end{array}$ & 0 & 0.0 & 28 & 13.9 & 67 & 33.3 & 106 & 52.7 & 201 & 100 \\
\hline
\end{tabular}

In this way, the results of the pedagogical leadership variable allowed us to know the perception of the instructors about the pedagogical leadership exercised by the management in the SENA training centres, identifying $33.3 \%$ of instructors who identify a level of pedagogical leadership that is fair, $35.8 \%$ good and $39.8 \%$ very good.

Likewise, with regard to the analysis of the educational management variable and its dimensions, it was found that of the total of 201 instructors, $16.9 \%$ perceive the level of goal setting and evaluation by the management to be fair, $45.2 \%$ a good level and $37.8 \%$ a very good level. Meanwhile, with regard to the second dimension, $2.9 \%$ of trainers perceive a poor level of strategic resource management, $21.3 \%$ a fair level, $45.7 \%$ a good level and $29.8 \%$ a very good level Table III.

Table II. Levels of distribution of the dimensions of

\begin{tabular}{lcccccccccccc}
\multicolumn{10}{c}{ educational management. } \\
& Poor & \multicolumn{1}{c}{ Fair } & & Good & Very good & \multicolumn{2}{c}{ Total } & \\
& $\mathrm{n}$ & $\%$ & $\mathrm{n}$ & $\%$ & $\mathrm{n}$ & $\%$ & $\mathrm{n}$ & $\%$ & $\mathrm{n}$ & $\%$ \\
\hline $\begin{array}{l}\text { Goal setting and } \\
\text { evaluation }\end{array}$ & 0 & 0.0 & 34 & 16.9 & 91 & 45.2 & 76 & 37.8 & 201 & 100 \\
$\begin{array}{l}\text { Strategic } \\
\begin{array}{l}\text { resource } \\
\text { management }\end{array}\end{array}$ & 6 & 2.9 & 43 & 21.3 & 92 & 45.7 & 60 & 29.8 & 201 & 100 \\
\hline
\end{tabular}

In this way, compared to the general perception of the instructors surveyed, $1 \%$ consider the educational management of the training centres' teaching managers to be fair, $38.3 \%$ consider it to be very good, and $60.7 \%$ consider the educational management of the institution's leaders to be very good.

Table III. Levels of distribution of educational management.

\begin{tabular}{llll}
\hline Educational management & & \\
& & $\begin{array}{l}\text { Frequency } \\
\text { Percentage }\end{array}$ & Frequency Percentage \\
\hline \multirow{2}{*}{ Valid } & Regular & 2 & 1,0 \\
& & 77 & 38,3 \\
& Good & 122 & 60,7 \\
& Very good & 201 & 100,0 \\
\hline
\end{tabular}


Finally, the analysis of the teaching practice variable and its dimensions showed that, of the total sample defined, $18.9 \%$ of the instructors perceived the management's accompaniment of the training processes to be fair, $52.2 \%$ a good level and $28.8 \%$ a very good level. With regard to the second dimension associated with the victimisation of the teaching staff in management activities, $26.3 \%$ of the trainers perceive the level of management to be fair, $49.7 \%$ a good level and $20.4 \%$ a very good level Table IV.

Table IV. Levels of distribution of the dimensions of teaching practice.

\begin{tabular}{lllllllllllll}
\hline & Poor & & Fair & & Good & & $\begin{array}{l}\text { Very } \\
\text { good }\end{array}$ & \multicolumn{2}{c}{ Total } & \\
& & & & & & & & & & & & \\
& $\mathrm{n}$ & $\%$ & $\mathrm{n}$ & $\%$ & $\mathrm{n}$ & $\%$ & $\mathrm{n}$ & $\%$ & $\mathrm{n}$ & $\%$ \\
\hline $\begin{array}{l}\text { Accompanying } \\
\text { training } \\
\text { processes }\end{array}$ & 0 & 0.00 & 38 & 18.9 & 105 & 52.2 & 58 & 28.8 & 201 & 100 \\
$\begin{array}{l}\text { Involvement of } \\
\text { teaching staff in } \\
\text { managerial } \\
\text { activities }\end{array}$ & 7 & 3.48 & 53 & 26.3 & 100 & 49.7 & 41 & 20.4 & 201 & 100 \\
\hline
\end{tabular}

Thus, with regard to the total perception of the instructors in relation to management and teaching practice, it was identified that $2.9 \%$ perceive a fair level, $37.3 \%$ a good level and $59 \%$ a very good level.

Table V. Levels of distribution of teaching practice.

Teaching practice

\begin{tabular}{llll} 
& & Frequency & Percentage \\
\hline \multirow{3}{*}{ Valid } & Regular & 6 & 2,9 \\
& Good & 75 & 37,3 \\
& Very good & 120 & 59,7 \\
& Total & 201 & 100,0 \\
\hline
\end{tabular}

\section{B. Inferential analysis}

Tabla VI. Ajuste de modelos.

Criterios de ajusteContraste de la razón de modelo de verosimilitud Logaritmo de la

Modelo verosimilitud -2 Chi-cuadrado gl Sig.

$\begin{array}{ll}\text { Sólo } & 71,444\end{array}$

Final 33,415 $38,029 \quad 4,000$

Likewise, with regard to the testing of specific hypothesis 1 , a value of sig. $=0.002<0.05$ was obtained, therefore the null hypothesis is rejected and the alternative hypothesis is accepted, i.e. that the pedagogical leadership of the management and educational management influences the accompaniment of the training processes of SENA - 2020, with a level of influence of $9.1 \%$ according to the R2 Nagelkerke.

The null hypothesis is rejected and the alternative hypothesis is accepted, i.e. that the pedagogical leadership of the management and educational management influence the involvement of teachers in management activities in SENA - 2020, with a level of influence of $17.9 \%$ according to the R2 Nagelkerke.

\section{Descriptive Qualitative Analysis}

The results of the qualitative study were established from the process of coding, analysis and interpretation of the information collected through the application of the semistructured interview guide instrument applied to the teaching managers of different SENA regional and training centres. The analysis of the information began with the transcription of the material obtained from the application of the interview guide. The participants' responses were compiled into a total of 35 pages, which were processed and coded in the Atlas Ti Software Version. 8.4.25.

In the framework of the development of the relationships that are generated through a previous list of codes, important results are denoted with each of the categories of the study, being able to identify in the analysis of the answers of the participants, the value of density that allows measuring the level of relationship with other codes or memos and of rootedness that defines the level of linkage of a code to a quote that is a referent of the answer of a participant in the interviews. Table VII shows the numerical value of the coding process carried out and allows us to deduce that for the category of pedagogical leadership, the code with the highest level of density is pedagogical training and rootedness and distribution of leadership. For the educational management category, the code with the highest level of density was academic actions and rootedness administrative actions, and for the teaching practice category, the code with the highest level of density was teacher training and rootedness pedagogical accompaniment.

Table VII. Level of rootedness and density of codes of analysis

\begin{tabular}{|c|c|c|c|}
\hline Código & $\begin{array}{l}\text { Enrai } \\
\text { zamie } \\
\text { nto } \\
\end{array}$ & $\begin{array}{l}\text { Densid } \\
\text { ad }\end{array}$ & $\begin{array}{l}\text { Grupos } \\
\text { códigos }\end{array}$ \\
\hline $\begin{array}{l}\text { Academic } \\
\text { actions }\end{array}$ & 10 & 6 & $\begin{array}{l}\text { Educational } \\
\text { management }\end{array}$ \\
\hline $\begin{array}{l}\text { Administrative } \\
\text { actions }\end{array}$ & 13 & 4 & $\begin{array}{l}\text { Educational } \\
\text { management }\end{array}$ \\
\hline $\begin{array}{l}\text { Pedagogical } \\
\text { accompaniment }\end{array}$ & 8 & 4 & $\begin{array}{l}\text { Teaching } \\
\text { practice }\end{array}$ \\
\hline $\begin{array}{l}\text { Institutional } \\
\text { ownership }\end{array}$ & 8 & 2 & $\begin{array}{l}\text { Educational } \\
\text { management }\end{array}$ \\
\hline Teacher training & 4 & 5 & $\begin{array}{l}\text { Teaching } \\
\text { practice }\end{array}$ \\
\hline $\begin{array}{l}\text { Distribution of } \\
\text { leadership }\end{array}$ & 8 & 1 & $\begin{array}{l}\text { Pedagogical } \\
\text { leadership }\end{array}$ \\
\hline $\begin{array}{l}\text { Institutional } \\
\text { evaluation }\end{array}$ & 6 & 2 & $\begin{array}{l}\text { Educational } \\
\text { management }\end{array}$ \\
\hline $\begin{array}{l}\text { Academic } \\
\text { training }\end{array}$ & 6 & 4 & $\begin{array}{l}\text { Pedagogical } \\
\text { leadership }\end{array}$ \\
\hline $\begin{array}{l}\text { Institutional } \\
\text { resource } \\
\text { management }\end{array}$ & 2 & 1 & $\begin{array}{l}\text { Educational } \\
\text { management }\end{array}$ \\
\hline $\begin{array}{l}\text { Faculty } \\
\text { motivation }\end{array}$ & 6 & 2 & $\begin{array}{l}\text { Teaching } \\
\text { practice }\end{array}$ \\
\hline $\begin{array}{l}\text { Educational } \\
\text { policy }\end{array}$ & 7 & 2 & $\begin{array}{l}\text { Educational } \\
\text { management }\end{array}$ \\
\hline $\begin{array}{l}\text { Participation in } \\
\text { networks }\end{array}$ & 5 & 2 & $\begin{array}{l}\text { Pedagogical } \\
\text { leadership }\end{array}$ \\
\hline Regulation & 7 & 1 & Teaching \\
\hline
\end{tabular}


T

\begin{tabular}{llll}
\hline $\begin{array}{l}\text { academic } \\
\text { activities }\end{array}$ & & & practice \\
$\begin{array}{l}\text { Supervision } \\
\text { pedagogical }\end{array}$ & 4 & 1 & $\begin{array}{l}\text { Teaching } \\
\text { practice }\end{array}$ \\
$\begin{array}{l}\text { activities } \\
\begin{array}{l}\text { Collaborative } \\
\text { work }\end{array}\end{array}$ & 6 & 3 & $\begin{array}{l}\text { Pedagogical } \\
\text { leadership }\end{array}$ \\
\hline
\end{tabular}

The above is congruent with the analysis of the interpretation of the information obtained from the participants, the perception on the part of the teaching managers and area leaders of the lack of training in subjects associated with educational leadership, educational management, educational administration and decisionmaking, as well as the fact that the educational leaders were directly involved in the management of the schools in which they carry out both academic and administrative actions within the framework of their functions, The influence of the pedagogical leader was identified directly in the educational management of the centres in which both academic and administrative actions are developed within the framework of their functions, and at the same time, the importance and relevance of permanent pedagogical accompaniment in teaching practice and teacher training was recognised, which should enable the competences of the whole team to be qualified in order to respond with quality teaching-learning processes.

The following is a word cloud, which shows the key aspects most frequently mentioned in the participants' answers to the questions that made it possible to respond to the research objectives, including training, instructors, apprentices, processes, work, quality, team and leadership.

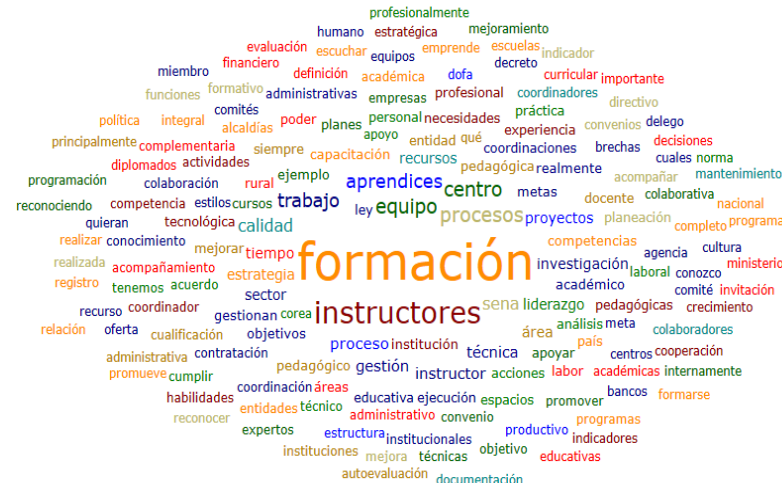

Fig 1. Word cloud Software Atlas TI V8.7.25

The analysis of the information obtained and the triangulation process, allowed to know according to the specific objective 1 , to determine the influence of the pedagogical leadership of the direction and educational management in the accompaniment to the formative processes of SENA - 2020, that there is a relationship of influence of the pedagogical leadership and educational management in the accompaniment to the formative processes of SENA. This relationship is framed through actions to motivate teachers. All this through the exercise of pedagogical and distributed leadership in which collaborative work is promoted, participation in networks and the academic training of the entire team in which participation is encouraged in both academic and administrative actions by assuming ownership of both guidelines and regulations and functions of the processes under their charge Fig 2.

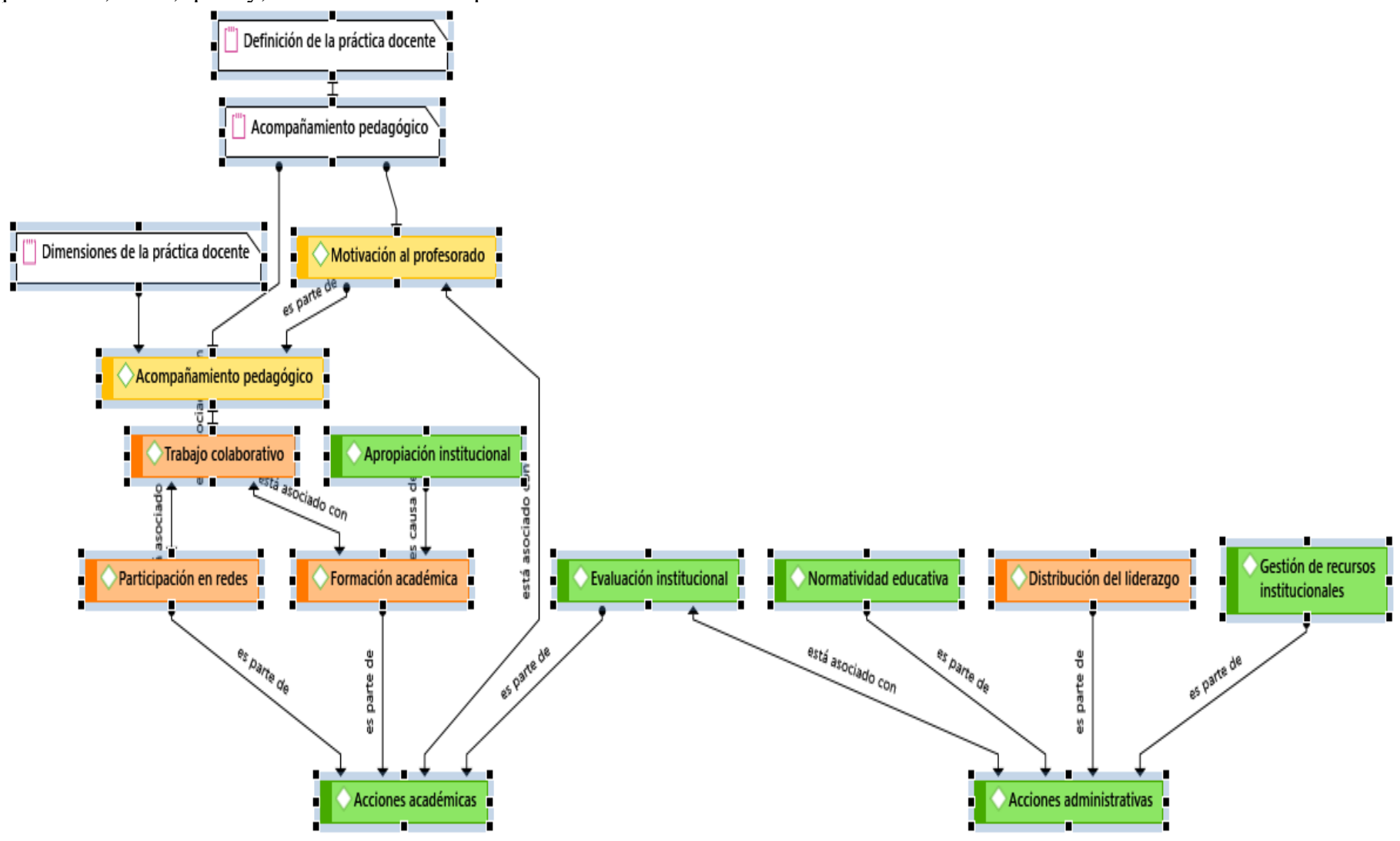

Fig 2. Relationships between codes of the subcategory pedagogical accompaniment. 
T

Likewise, in accordance with specific objective 2, to determine the influence of pedagogical leadership and educational management on the recruitment of teachers in management activities in SENA - 2020, it was found that there is a relationship of influence of pedagogical leadership and educational management on the recruitment of teachers in management activities in SENA. This relationship of influence on the part of the pedagogical leader is established by the ability of the teaching managers to recognise the aptitudes of their collaborators, the definition of profiles, the assignment of both academic and administrative functions that make it possible to regulate the activities associated with the leader, and from relationships that are based on principles of trust, autonomy and consensual decisionmaking in which it is possible to reach agreements in the determination of institutional purposes, achieving a followup and evaluation mediated through performance objectives Fig 3.

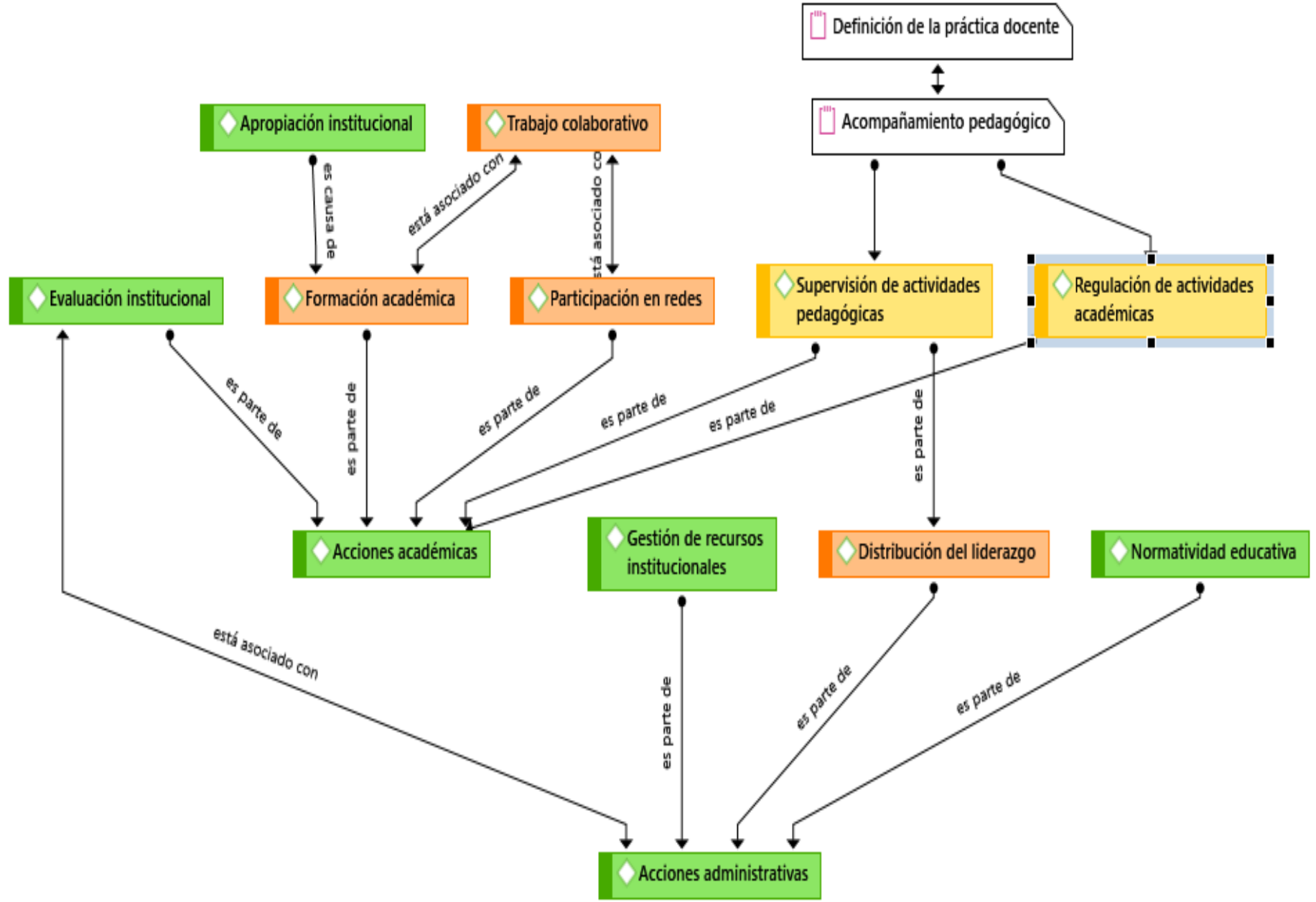

Fig 3. Relationships between codes of the subcategory teacher attachment.

\section{Discussion}

The results of the study in its quantitative and qualitative phase, showed in accordance with the general objective, that there is an influence of pedagogical leadership of management and management on teaching practice. From the implementation of the Chi-square statistical test, a pvalue of 0.000 was obtained, identifying a $\mathrm{p}$-value $<0.05$, allowing the general hypothesis to be accepted and the null hypothesis to be rejected, with a level of influence according to the R2 Nagelkerke coefficient of determination of $21.8 \%$. Likewise, from the qualitative analysis, in the category of pedagogical leadership, there was evidence of relationships of influence in which associations of pedagogical leadership were observed with academic training, participation in networks and collaborative work, and relationships of belonging with the definition of administrative actions, academic actions, and the distribution of leadership. This coincides significantly with the research that sought to identify the pedagogical leadership exercised by the teaching directors of the social communication and journalism programme of the Corporación Universitaria Minuto de Dios in Colombia. The study with a quantitative approach and a non-experimental design, showed in the application of the Multifactorial Leadership Questionnaire instrument to 7 teaching managers, that there is a high level of incidence of the leadership style assumed by the pedagogical leaders in the educational communities. In this way, pedagogical leadership was determined to be based on the management of relationships with people and processes, involving both transactional and transformational leadership [1].

This position is shared with the results of the study that aimed to determine the relationship between top management leadership as a decision and the assumption of pedagogical leadership style as a choice in terms of learning in educational institutions. This research, with a quantitative, correlational, cross-sectional approach and an 
exploratory design, showed a moderate positive correlation between leadership style and organisational learning, arguing that top managers in an educational organisation are characterised by a style that is transactional and transformational [32]. However, other authors state that, although several studies reflect the need for relationshipbased pedagogical leadership to improve the development of both academic and social learning, this is often limited by the public and top-down structure of institutions. This situation is not indifferent to SENA, due to its vertical and hierarchical organisational structure [7].

Thus, according to the results of this research, pedagogical leadership associated with the theory of relationships [2], [30], in which the pedagogical leader is described as a transformational leadership style that recognises the work of his followers and enhances the work of his team, a transactional leadership style, which aims to achieve institutional goals and objectives, and a distributed leadership style, which encourages participation in work teams based on the delegation of functions, achieving the development of people, the redesign of the organisation, and the management of teaching-learning processes [31].

Thus, by understanding the reality of the educational context in which the dynamics of the process of comprehensive vocational training in SENA are developed, a significant contribution is made in recognising pedagogical leadership, which is described from their ability to collaborate and cooperate in academic networks, delegate functions, recognise the skills of their work team and direct the training centres to a state of organisational development that involves the entire educational community in search of the effectiveness and efficiency of the processes of educational management and teaching practice that they lead.

Similarly, when determining the influence of the pedagogical leadership of the management and educational management in the accompaniment of the SENA - 2020 training processes, a moderate level of influence of $9.1 \%$ was identified from the quantitative approach, and from the qualitative approach, association relationships mediated by teacher motivation, which indicates the influence of the management teams in the educational community and especially in the accompaniment processes in the development of the teaching-learning processes, which potentiates the work of teachers and thus the quality of student learning [21]. However, this is only possible through the development of collaborative and cooperative relationships with the external community without the cohesion or limitation of endogenous factors in its management [7].

\section{Conclusions}

It is concluded according to the sig. value $=0.000<0.05$, obtained, that there is an influence of the pedagogical leadership of the educational direction and management on the teaching practice of the SENA, with a level of influence of $21.8 \%$ according to the R2 Nagelkerke. This is argued from the results of the qualitative analysis and the theory presented. In which it was identified from the understanding of the realities of the pedagogical leaders of the training centres, the definition of a distributed style [31], which is structured for SENA, under the concept of vertical structures at the organisational level, in which directions and areas of work are defined in which teams participate according to their expertise and experience in the specific execution of functions. Likewise, the capacities of teaching managers are recognised in relation to their ability to distribute functions, their ability to influence, motivate and incentivise their followers and promote teacher development, their ability to lead the team towards institutional objectives and goals, and their ability to manage interpersonal relations and resolve conflicts [5]. However, although there is a positive relationship of influence, factors are identified that limit the management, strategic, administrative and academic processes by denoting the lack of professional preparation in related programmes such as administration or educational management, also, given the vertical institutional structure, although there is autonomy in decision-making within each training centre, this is manifested by the participants as limited, while it requires constant approval by senior management.

Similarly, the influence of the pedagogical leadership of the management and educational management in the pedagogical support of teachers was verified, with a level of influence of $9.1 \%$, which indicates the commitment of the teaching managers to participate in the pedagogical and training process of the apprentices [5], as they recognise that the mission objective of their work is the comprehensive professional training of people who contribute satisfactorily to the country's productive sector.

Likewise, the influence of the pedagogical leadership of the educational direction and management on the involvement of teachers in management activities was determined, with a level of influence of $17.9 \%$ according to the R2 Nagelkerke, which indicates the application by educational leaders in the exercise of their functions, of a constant practice of learning with their work team, which promotes the involvement of teachers in academic and administrative actions, under principles of autonomy, the management of relationships and pedagogical leadership that recognises the importance of delegating and assigning responsibilities [31].

\section{References}

[1] D. Acosta \& E. Ponce, "Leadership Styles in Higher Education", Conrado, vol. 15, no. 68, pp. 175-179, May. 2019.

[2] V. Almirón, A. Tikhomirova, A. Trejo, y J. García-Ramírez, "Transactional Leadership vs. Transformational Leadership," Reidocrea, vol 4, art 4, pp. 24-27. Fab. 2015.

[3] R. L. Andrews \& M. R, Bansom, "Instructional leadership: Supervision that makes a difference", Theory into practice, vol. 30, no. 2, pp. 97-101, Nov. 2009.

[4] A. Bolívar"Educational leadership and its role in improvement: a current review of its possibilities and limitations"., 
Psicoperspectivas, vol. 9, no. 2, pp. 9-33. Aug. 2010.

[5] Bolívar, A school management with pedagogical leadership capacity. Madrid: La Muralla, 2019.

[6] I.Bravo, A. Díaz, C. Navarrete, C. Pérez, C. Cuevas, C. Nova, y M. Albornoz, "Assessment of the influence of a management support programme on the perception and job satisfaction of teachers and managers",Universitas Psychologica, vol. 16, no. 2, pp. 1-10. April. 2017.

[7] A.B. Botía, K. C. Rodríguez \& M. GarcíaGarnica", Multidimensional assessment of pedagogical leadership: keys to school improvement", Ensaio: Avaliação e Políticas Públicas em Educação, vol. 25, no. 95, pp. 483-506, Jan. 2017.

[8] I.Bulgaru, "Study on management styles of the teacher", Procedia-Social and Behavioral Sciences, no. 180, pp. 144-149, Nov. 2015.

[9] A.K.H. Espinoza, M. L. S. Antelo \& M. L. M. Serrano, "Teaching practice of university lecturers: their learning context. Revista de Currículum y Formación de Profesorado, vol. 19, no. 2, pp. 215-224. Aug. 2015.

[10] J. T. Fernández, M. L. Carvalho \& C. R. Bueno, "Practicum in teacher training: perceptions of the protagonists". Revista Internacional de Investigación en Educación, vol. 9, no. 19, pp. 91-114, Jan. 2017.

[11] J.O. Galván \& G. M. Farías"Personal characteristics and teaching practice of university teachers and their relationship with performance evaluation", RIEE. Revista Iberoamericana de Evaluación Educativa, vol. 11, no. 2, pp. 9-33. Jan. 2018.

[12] F. J. García, S. C. Hernández y L. Salgado, "School management and educational quality". Revista Cubana, vol. 37, no. 2, pp. 206-216, Feb, 2018.

[13] M. García-Garnica, "Development and validation of a questionnaire to measure effective managerial pedagogical leadership practices", Profesorado, Revista de Currículum y Formación del profesorado, vol. 20, no. 3, pp. 493-596, July. 2016.

[14] H. Gardner, y K. Davis. The APP generation. How young people manage their identity, their privacy and their imagination in the digital world. Bogotá: Planeta, 2014.

[15] W. Grift, "Educational leadership and academic achievement in elementary education," School Effectiveness and School Improvement, vol. 1, no. 1, pp. 2640, July. 2006.

[16] R. Hernández-Sampieri \& C. P. M. Torres. Research methodology (Vol. 4). México^ eD. F DF: McGraw-Hill Interamericana, 2018.

[17] E. L. M. Huamán \& S. V. Villanueva, "School management and organisational commitment in the achievement of Intercultural Bilingual Education learning at primary level"., Revista Muro de la Investigación, vol. 3, no. 1, pp. 1-12. Dec. 2018.

[18] M. A. López-Paredes, "Pedagogical management. Notes for a necessary study. Science domain", vol. 3, no. 1, pp. 201215, Mar. 2017.

[19] J. MacBeath, "Leadership as distributed: A matter of practice", School leadership and management, vol. 25 , no. 4, pp. 349-366. Aug. 2005.

[20] E. Macías, S. Chum, C. Aray, y C. Rodríguez, "Liderazgo académico: estilos y perfiles de gestión en las instituciones de educación superior", Rehuso., vol. 3, no. 1, pp. 59-70, Jan. 2018.

[21] O. J. Maureira, "Educational leadership practices: An evolutionary and illustrative look at its main frameworks, dimensions and most representative indicators", Revista Educación, vol. 42, no. 1, pp. 119, Jan, 2018.

[22] I. Oplatka, "The emergence of educational management as a field of study in Latin America", Revista Eletrônica de 
Educação, vol. 13, no. 1, pp. 196-210, Jan. 2019.

[23] J. E. Parra-Martínez, "Effective management in education and its importance in educational management action in Colombia", Aibi revista de investigación, administración e ingeniería, vol. 5, no. 2, pp. 16-22, Jan. 2017.

[24] B. Pont, D. Nusche y H. Moorman. Improving school leadership. Paris, OCDE, 2008.

[25] S. O. Requena y J. C. Ribera, "Leadership and educational legislation as foundations for school management. A descriptive study in the context of Catalonia", Profesorado, Revista de Currículum y Formación del Profesorado, vol. 23, no. 2, pp.41-58, July. 2019.

[26] M. Rodriguez-Gallego, R. Ordoñez-Sierra, y A. López-Martinez. "School leadership: Pedagogical leadership and school improvement". Revista de Investigación Educativa, vol.38, no.1, pp. 275-292, Sep. 2020.

[27] C. Romero, "Leadership in schools that overcome contextual barriers". REICE. Revista Iberoamericana sobre Calidad, Eficacia y Cambio en Educación, vol. 19, no. 1, pp. 73-90, Jan. 2021.

[28] P. Senge. The Fifth Discipline Fieldbook: Strategies and Tools for Building a Learning Organization. New York: Currency, Doubleday, 1994.

[29] S. Sirisookslip, W. Ariratana \& T.K. Ngang, "The impact of leadership styles of school administrators on affecting teacher effectiveness", Procedia-Social and Behavioral Sciences, vol. 186, pp. 1031103, May. 2015.

[30] A. Sonnenfeld, Ethical leadership: the wisdom of deciding well, Pearson, 2016.

[31] J. P. Spillane y M. Ortíz, Distributed perspective of leadership and school management: crucial elements and implications", Revista Eletrônica de Educação, vol. 13, no. 1, pp. 169-181, Jan. 2019.
[32] M. Villar \& L. A. Araya, "Consistency between leadership approach and leadership styles: key to transformation and change", Revista científica Pensamiento y Gestión, no. 46, pp. 187221, Jan. 2019.

[33] M. Villalobos, "Leadership" Avances en Enfermería, vol 8, no. 1, pp. 14-24. July. 1990.

[34] J. Weinstein, J \& M. Hernández, "Birth pains: emerging school leadership policies in eight school systems of Latin America", international Journal of Leadership in Education, vol. 19, no. 3, pp. 241-263. Apr. 2015.

[35] J. Weinstein, C. Cuellar, M. Hernández y M. Fernández, "Director for the first time: a study on the experience and socialisation of novice principals in municipal schools in Chile", Calidad en la Educación, no. 44, pp. 12-45, July. 2016.

[36] J. S. Yangali, J. L. R. López \& J. G. C. Ardiles, "The relationship of decisionmaking and educational management in teacher managers at the university",INNOVA Research Journal, vol. 3, no. 8.1, pp. 60-76. Sep. 2018.

[37] M. A. R. Zuñiga, Educational management and teaching practice: reflections on the research dimension". Ciencia y Educación, vol. 1, no. 2, pp. 59-75. Feb. 2020. 